\title{
ダルモーッタラの直接知覚論 その独自性と理論的背景
}

\section{西 沢 史 仁}

筆者は，以前，ダルマキールティの一連の論理学書には，直接知覚に対象確定 作用（niścaya）を認める記述と認めない記述の二つが混在していることを指摘し， それに関するシャーキャブッディとアルチャタの解釈を紹介した（西沢 2013）. そこで，この両者は，直接知覚は無分別知であるので対象確定作用を認めないこ と，及び，直接知覚に対象確定作用を認めるダルマキールティの記述は，比喻的 表現（upacāra）であると会通することを明らかにした．本稿では，直接知覚と対 象確定作用に関するダルモーッタラ（Dharmottara）の解釈を検討したい. 彼の解 釈は，ゴク翻訳師（rNgog lo tsā ba, 1059-1109）を通じてチベットに伝えられ，後代， チベットにおいて大きな影響力を持ったものである.

\section{1 .ダルモーッタラの論理学書に見られる直接知覚と対象確定作用に関 する記述}

まず最初に，ダルモーッタラの一連の著作には，直接知覚に対象確定作用を認 める記述が散見することが注目に值する。以下，幾つか例を挙げておく．

用例 1：「知覚されたものとして判断する直接知覚 (lhag par zhen pa'i mngon sum) により

対象（=行動対象）が示されたが,」(PPar, p. 22.14-15)

用例 2:「直接知覚と推論は，《獲得させるもの》の支分である《判断するもの (zhen par byed pa)》であることにより，示されたものを獲得させるものであるので，認識手段 である.」(PPar, p. 52.19-21)

用例 3：「それ故，判断を為してこそ(adhyavasāyam kurvad eva)，直接知覚は認識手段で ある.」(NBT, p. 84.5)

用例 4：「直接知覚の認識手段性もまた，‥顕現を確定することから (snang ba nges par byed pa las) [成立する] のである.」(PVinT, p. 46.4-6)

ここで「判断」と訳した adhyavasāya（Tib. lhag par zhen pa / zhen pa）とは，例えば， 「これは壼である」等と対象を確定する知，ないし，その知の作用を意味する。 それは,「断定 (pariccheda)」や「確定 (niścaya)」とほぼ同義として用いられるね）。 


\section{2. 直接知覚と対象確定作用に関するダルモーッタラの基本的見解}

通常, 判断は, 分別知 (vikalpa), ないし, その作用と見做されており, 無分別 な直接知覚には判断作用は認められないと解するのが一般的であるが, ダル モーッタラがその点を如何に解釈していたのかという点が検討課題となる。結論 を先取りするならば，ダルモーッタラにとっても，直接知覚は無分別知であるの で，それ自身としては対象を確定することはできない．しかし，判断ないし分別 知と共働することを通じて, 対象を確定するというのがダルモーッタラの基本的 な解釈である。この点については，『量性考察』に極めて示唆的かつ重要な文章 が見出されるので，引いておこう。

それ故，直接知覚は，分別知という木馬に跨り[対象を］確定するもの（rnam par rtog pa'i shing rta la zhon nas nges par byed pa) であると知られるべきであるが, [直接知覚]そ れ自身は無分別知であるので，[それ自身として，対象を］確定するものではないので ある. 判断されたものを示すものは, 直接知覚であり, 分別知は, 直接知覚とは別に, [対象を] 確定するものではないが, 直接知覚は, 判断を本性とするものとして, 判断 すると認められるのではなく，前述した仕方で［判断すると認められるの］である.（PPar， pp. 50.15-51.2)

ダルモーッタラの著作には, 先に挙げたように, 一見して, 直接知覚自身が対 象を確定する，あるいは対象を判断するような記述が散見するが，ここで彼は， 直接知覚は無分別知であるという理由により，直接知覚それ自身が対象を確定す ることを明確に否定している。しかし，直接知覚が，或る特定の条件の下で，即 ち，「分別知という木馬に跨る」仕方で，対象を確定することを認めて扔り，そ の点で, シャーキャブッディ等と解釈を異にする．この比喻的な表現が示唆して いるのは, 直接知覚は, 分別知 (=判断) と共働 ( ${ }^{*}$ sahakāra) して対象を確定する ことである，例えば, 現前の壸を直接知覚により知覚しているとき, それを知覚 している状態において, 或る時, 「これは壼である」という喆を確定する分別知 が生ずる．複数の分別知が同時に同一の心相続において生ずることは認められな いが (PV III. 178b)，無分別知と分別知が同時に同一の心相続に共存することは認 められるのである。それ故, 例えば, 第一刹那において直接知覚が生じ, 次刹那 において対象を確定する分別知が生じた時, その第二刹那においては, 直前の直 接知覚を質料因として生じた直接知覚が分別知と共在することになる．ダル モーッタラによれば, 第二刹那の直接知覚は, 同時に存在する分別知と共㗢し て, 対象を確定する。このように, 判断と共働する形で対象を確定する直接知覚 
は，認識手段として，自らの行動対象を, 目的達成を望む人に《示すもの（pradarśana)》であり，それに対して人に《行動を起こさせるもの (pravartaka)》である. その判断との共働なくして, 対象が明暸に顕現するだけの直接知覚が単独で, 行 動対象を示したり，行動を起こさせることは不可能である．その意味で，判断 は，《認識手段の作用 (pramāṇavyāpāra)》であり，《行動の支分 (pravrttyanga)》ない し《獲得の支分 (prāptyaniga)》と称される。

判断こそが, 認識手段の作用（tshad ma’i bya ba, * pramānavyāpāra）であるので，それ故 にこそこれ（=判断）は，[認識手段の対象理解において］必ず為されるべきもの (gdon mi za bar bya ba, *avaśyakartavya，不可欠なもの) である. それ（=判断）を為す ことにより知が認識手段となるところの，それ（=判断）は，必ず為されるべきもので あるが，何であれその必ず為されるべきものもまた，結果であると云われる，‥ [ここ で「確定（nges pa, ${ }^{*}$ niścaya)」と云うのは，確立するもの（gtan la 'bebs pa）であり，判 断を云う.ここで判断とは, 獲得の支分 (thob pa’i yan lag, ${ }^{*}$ prāptyanga) を云うので, 「行 動を結果として有するもの（'jug pa’i 'bras bu can, *pravrttiphala)」とも説かれた. 行動の 支分 ('jug pa'i yan lag, * pravrttyanga) となっているので, 獲得の支分である判断は認識手 段 [の作用? $]^{2)}$ であるという意味である.（PPar, p. 40.12-21）

この記述は，判断と認識手段に関するダルモーッタラの基本的見解が簡潔に纏 められている点で重要である。判断は, 認識手段ではないが, 認識手段の対象理 解に不可欠な要素である。さらに，例えば「これは青である」という判断を為す ことにより，その判断と共働した直接知覚が認識手段として設定されるので，そ の直接知覚は，その判断によって《設定されるべきもの (vyavasthāpya)》である. 他方，判断は，その直接知覚を認識手段として《設定するもの (vyavasthāpaka)》 である.ダルモーッタラの認識論では, 判断と直接知覚は《設定するもの》と 《設定されるべきもの》として規定される。即ち，

《設定するもの (vyavasthāpaka)》とは，直接知覚の力によって生じた分別知（vikalpapratyayah pratyakșabalotpannah, i.e., adhyavasāya) であると見なされるべきである. 他方, 無 分別であるので, 直接知覚のみでは, 青の理解（bodha, i.e., niścaya）を自体とするもの として，自身を設定することが出来ない，確定知により設定されない，青の理解を自体 とする知は，有るとしても，無いのと同様のものに他ならない，それ故，確定によって 青の理解を自体とするものとして設定された知（=青を理解する直接知覚）は，青の理 解を本性とするものとして，存在することになる，それ故，判断を為してこそ，直接知 覚は認識手段である，他方，判断が為されないとき，青の理解を自体とするものとし て，その知は設定されないのである. 同様に, 対象の理解を自体とする認識結果は完成 しない。それ故, 最大の能立であることがないので, その知（=判断を為さない直接知 


\section{覚)は，決して認識手段でないことになる.（NBT, p. 84.1-7）}

青を把握した直接知覚の力によって生じた分別知により，青を把握した直接知 覚が, 青を理解することを自体とするものとして設定される。これは, 即ち, こ の分別知と共働した直接知覚により青が理解（=確定）されたことを意味する. なぜならば，この設定が為されないならば，無分別の直接知覚は，青を理解する ものとして存在しないからである。 その意味で, 「判断を為してこそ, 直接知覚 は認識手段である」と云われるのである。これは, 直接知覚と同時に存在する判 断が直接知覚と共働して対象を確定することを通じて, 初めて, その直接知覚は 認識手段として設定される，あるいは，認識手段となる，という意味であり，そ の意味で, 判断は直接知覚を《認識手段化》する, その際, 判断は, 或る意味, 自らの対象確定作用を直接知覚に付与すると言うことが許されるかもしれない。 ダルモーッタラの論理学書に見られる, 直接知覚に対象確定作用を認める一連の 記述は，以上のように解釈する必要がある。

\section{3. 直接知覚に認識手段とそうでないものの二つの部分があること}

このように考える場合，直前に引いた『正理一滴註』に明記されているように, ダルモーッタラの認識論では, 直接知覚であったとしても, 必ずしも認識手段で あるとは限らないことになる，即ち，直接知覚の対象認識においては，(1）先ず 最初に, 対象が明瞭に顕現するだけの知が生ずる。これは, 離分別不迷乱の知で あるので，直接知覚であるが，この段階では，まだ对象の理解は生じておらず， 対象に対して行動を惹起することができないので，認識手段として設定されない。 （2）その後に, 判断が生じ, 直接知覚はその判断と共㗢することを通じて, 対象 を理解する.この対象を理解した段階で, 初めて, この直接知覚は, 人に行動対 象を示し，それに対して行動を起こさせることが可能となるので，認識手段とし て設定される。

1. 判断と共働して対象を理解する前の段階での直接知覚 $\neq$ 認識手段

2. 判断と共働して対象を理解した段階での直接知覚 $=$ 認識手段

以上のようなダルモーッタラの特異な解釈は, 彼の独自の認識手段論を理論的 背景としている.ダルモーッタラは, 認識手段の定義である無欺性（avisamvāadakatva） を, 《対象獲得能力 (arthaprāpanaśakti)》と解釈するので, 認識手段であるならば, それに基づき，人が行動を起こして自身の目的を達成する対象を獲得させる知で ある必要がある，問題は，直接知覚であり，端的には，対象が明暸に顕現するだ 
けの受動的な知である直接知覚に, 如何に対象獲得能力という能動的な力をリン クさせるのかという点である.なぜならば，人が対象に対して行動を起こす為に は，その対象を確定・理解する必要があるからであり，単に対象が顕現している だけの知には，人に行動を葆起する能力はないからである。それを解決する手立 てが，「直接知覚は，分別知という木馬に跨がり，対象を確定する」という理論 である，直接知覚は，それ自身としては，対象を確定しないが，分別知と共働す ることを通じて，対象を確定し，対象に対して人に行動を引き起こし，対象を獲 得させることが出来ると解釈することで，この難問の解決を図ったわけである.

このように，条件付きではあるが直接知覚に対象確定作用を認めるダルモーッ タラの解釈は, ゴク翻訳師を通じて，様々な変容と䛊解を伴う形ではあるが，千 ベットに伝承された。ゴク翻訳師は，直接知覚に対象確定作用を認め，対象が明 瞭に顕現するが, 確定されない知として, 《顕現不確定知 (snang la ma nges pa'i blo)》 という非認識手段の知を案出したと推察される（西沢 2012，pp. 113-115）。他方, 直接知覚に，認識手段と非認識手段の知を分ける考えは，チャパ (Phya pa chos kyi seng ge, 1109-1169）の論理学書に見られ，その設定はサパン（Sa paṇ, 1182-1251） により批判されたが，ゲルク派には自説として受容された. その詳細について は，別稿にて紹介したい。

\section{4. 直接知覚と判断の集合体ではなく，直接知覚のみが認識手段である こと}

このように, ダルモーッタラの認識論においては, 直接知覚は, 判断と共動す ることにより初めて, 対象を確定・理解することができる認識手段として設定さ れることが判明した．しかし，このことは，直接知覚が判断を伴うものとしての み認識手段として認められることを意味するわけではない，直接知覚が，認識手 段と認められるには，判断との共働が不可欠であるが，認識手段として立てられ るのは, あくまで直接知覚のみであり, 判断を伴う直接知覚, ないし, 直接知覚 と判断の集合体ではない．この点について，ダルモーッタラはこう明言している.

[問い：］もし，このように，判断を伴うもの（adhyavasāyasahita）としてのみ，直接知 覚が認識手段となり，単独では［直接知覚は認識手段では］ない，と云うならば，[回 答: ] そうではない，‥⿱あるる対象に対して，直接知覚を前提とする判断があるとき，そ の [対象]に対して, 単独の直接知覚のみが認識手段である. (NBT!, pp. 85.3-86.3) 


\section{結語}

以上，直接知覚と対象確定作用／判断に関するダルモーッタラの解釈を検討し た.シャーキャブッディやアルチャタは，無分別な直接知覚が対象を確定するこ とを認めないが，ダルモーッタラは，判断との共働という形で直接知覚に対象確 定作用という能動的な働きを認める点で立場を異にすることが判明した。さら に, 直接知覚は, 判断との共働により対象を理解する知として設定されない限り, 認識手段とは認められないので，ダルモーッタラの認識論では，直接知覚には， 認識手段と認識手段でないものの二つの部分が認められることになる，以上の点 に，ダルモーッタラの独自性が認められる。

1) Cf. Nyāyakośa, re-ed. V. Sh. Abhyankar (Poona: Bhandarkar Oriental Institute, 1978), p. 16.6: “idam evam eva” iti viṣayaparicchedo niścayah/。 こは，仏教徒及び非仏教徒の論理 学者の共通の規定であり, adhyavasāya の原義である。一方, ダルマキールティは，こ の adhyavasāya という概念を，特に，「乙でないものを乙と判断する知」という意味で も使用している点に特徴がある. adhyavasāya の詳細については, 先行研究の提示と 併せて，別稿にて論ずる予定である。

2 ）先行する文章に明記されているように, 判断は, 認識手段ではなく, 認識手段の作 用である。原文では，tshad ma とあるが，tshad ma”i bya ba の誤記か.

原典資料及び参考文献は，西沢 2013 所収文献表未記載のもののみを挙げておく.

〈原典資料〉 NBṬ：Dharmottara, Nyāyabinduti kiā. Ed. D. Malvania. Patna, 1971. PPar：Dharmottara, [Laghu-] Prāmānyaparīkșā. See Krasser 1991, vol. 1. PVinṬ: Dharmottara, Pramānaviniścayațīkā. See Steinkellner and Krasser 1989.

〈参考文献〉沖和史「ダルモーッタラの「量量果非別体論」一-Nyāyabinduṭikā における 一」『渡辺文榣博士追悼記念論集 - 原始仏教と大乗仏教』下, 永田文昌堂, 1993, pp. 119-136. 西沢史仁「非認識手段の知の起源に関する一考察」『インド哲学仏教学研究』 19 (2012), pp. 105-118. 同上「直接知覚と対象確定作用に関する再検討一ダルマキー ルティの相反する記述及び註釈者達の解釈——」『印仏研』61-2 (2013), pp. 115-120.

Ernst Steinkellner and Helmut Krasser. Dharmottaras Exkurs zur Definition gültiger Erkenntnis im Pramānaviniścaya. Wien: Österreichischen Akademie der Wissenschaften, 1989. Helmut Krasser. Dharmottaras kurze Untersuchung der Gültigkeit einer Erkenntnis Laghuprāmānyaparīkșā. 2 vols. Wien: Verlag der Österreichischen Akademie der Wissenschaften, 1991.

〈キーワード〉 ダルモーッタラ（Dharmottara）, 直接知覚（pratyakșa）, 確定（niścaya）, 判断 (adhyavasāya)，認識手段（pramāna）

(東京大学大学院修了, 博士 (文学)) 